\title{
An evaluation of frailty factors among elderly and their mutual links in elderly women in the Olomouc region
}

\author{
Tereza Kaplanová*, Miroslava Přidalová, and Vendula Zbořilová \\ Faculty of Physical Culture, Palacký University Olomouc, Olomouc, Czech Republic
}

Copyright: (C) 2017 T. Kaplanová et al. This is an open access article licensed under the Creative Commons Attribution License (http://creativecommons.org/licenses/by/4.0/).

Background: Ageing has a significant impact on the functional status and capacity in physical, cognitive, sensory and nutritional areas. The age-related changes include changes in body composition as well as changes in the musculoskeletal system including a significant loss of muscle mass and demineralization of bone. Objective: The aim of this study was to evaluate the relationship between selected parameters of frailty factors in older women from the Olomouc region. Methods: The research group consisted of 225 women (aged 60-81 years) attending University of the Third Age at the Faculty of Physical Culture, Palacký University Olomouc and women from senior clubs in Olomouc. Body composition was assessed by multifrequency bioelectrical impedance. Muscle strength in the hand flexors was evaluated using a digital pinch grip. Information on bone density was obtained through local densitometer. To verify the strength of relation between variables Pearson correlation coefficients were calculated. Results: Relationship between body composition, muscle strength and bone density proved to be statistically significant. Moderate positive correlation was found between the grip strengths of both hands, bone density of both calcaneus and the amount of fat-free mass, muscle mass, cell mass and the size of the basal metabolic rate in range from .41 to .49. The relationship between muscle strength and bone density was weak $(r<.30)$ but statistically significant. Conclusions: These results confirm the relationship between aspects of the frailty of elderly women, especially the relationship between muscle strength, bone density and selected parameters of body composition.

Keywords: body composition, aging, bone density, muscle strength

\section{Introduction}

Aging has a significant impact on the functional state and capacity in the physical, cognitive, sensory and nutritional areas. Changes in the individual fractions of body can be very substantive. A loss in total body water volume can be observed along with its individual components. Elderly people manifest $20 \mathrm{ml}$ less extracellular fluid per each kilogram of weight which for a person of $70 \mathrm{~kg}$ means a decrease by 1.51 (Gába, Riegerová, \& Přidalová, 2009; Kalvach, Zadák, Jirák, Zavázalová, \& Sucharda, 2004). There is also a decrease in lean body mass amounting to $1.5 \mathrm{~kg}$ according to certain authors (Forbes, 1999; Toth, Tchernof, Sites, \& Poehlman, 2000). Fat mass, in contrast, increases which shifts from the peripheral body

\footnotetext{
* Address for correspondence: Tereza Kaplanová, Department of Natural Sciences in Kinanthropology, Faculty of Physical Culture, Palacký University Olomouc, třída Míru 117, 77111 Olomouc, Czech Republic. E-mail: tereza.kaplanova@upol.cz
}

parts to the central abdominal area (Gába, Přidalová, \& Zajac-Gawlak, 2014; Hughes, Frontera, Roubenoff, Evans, \& Fiatarone Singh, 2002; Toth et al., 2000). This brings about an increase in fat mass in the upper part of the body (Gába et al., 2009; Toth et al., 2000).

The occurrence of functional limits of the musculoskeletal system in the elderly population is high and has been growing. Illnesses of the musculoskeletal system are the second most frequent category of illnesses directly after cardiovascular diseases (Pavelka \& Rovenský, 2003; Topinková, 2002). Age-related changes in the musculoskeletal system primarily include a significant loss in muscle and bone tissue. There is a decrease in muscle mass by $1.2 \%$ annually (Evans \& Campbell, 1993), and a decrease in muscle strength by $1.5 \%$ after the age of 50 and a reduction by $3 \%$ after the age of 60 (Berková, Berka, \& Topinková, 2013; Hughes et al., 2002; Thomas, 2007). Muscle weakness described as sarcopenia involves a loss of muscle mass, a reduction in the speed and strength of muscle contraction and states appropriate for denervation atrophy (Berková 
et al., 2013; Evans \& Campbell, 1993). Sarcopenia can lead to hypomobility, instability, disability or even loss in self-sufficiency. It can also lead to the development of immobility syndrome (Abellan van Kan et al., 2009; Cruz-Jentoft et al., 2010; Kalvach et al., 2004; Prokešová, Šteffl, Petr, \& Kohlíková, 2012; Suetta et al., 2009).

The decrease in the density of the bone tissue in the elderly population is related to changes in the musculoskeletal system and can lead to osteopenia or osteoporosis. There are 500,000 women and 200,000 men suffering from osteoporosis in the Czech Republic (Fried et al., 2001; NIH Consensus Development Panel on Osteoporosis Prevention, Diagnosis, and Therapy, 2001; Skrzek, Ignasiak, \& Koziel, 2011). Maximal bone density is reached at the age of 22 amongst women while maximum of bone mass is reached 4 years later (Teegarden et al., 1995). After the age of 40, a downturn in the new formation of bone tissue and a gradual loss of bone tissue by $0.7-1.0 \%$ per year occur (Gába \& Kapuš, 2012; Shephard, 1997; Spirduso, Macrae, \& Francis, 2005). The difficulties associated with bone density and the firmness of bones have become more significant due to increasing average life span (Lim et al., 2004; Skrzek et al., 2011, 2015; Warming, Hassager, \& Christiansen, 2002).

Each health limitation, even when small, can bring about a decrease in self-sufficiency. The restraints on mobility, coordination and postural stability in the elderly population are not only represented by the risk of obesity, which means the development of fat mass above the recommended framework, but also the risk of an occurrence of sarcopenia which is associated with insufficient development of the muscle component, or a weakening of the skeletal system which is associated with insufficient bone density. Somatodiagnostics is therefore essential in order to determine the current physical state which is closely linked to the functional capacity of the organism (Cesari, Landi, Vellas, Bernabei, \& Marzetti, 2014; Clegg, Young, Iliffe, Rikkert, \& Rockwood, 2013; Kalvach, Zadák, Jirák, Zavázalová, Holmerová, \& Weber, 2008; Rockwood, Hogan, \& MacKnight, 2000; Rodríguez-Mañas et al., 2013; Topinková, 2002).

The number of studies discussing changes in body composition in the elderly population, changes in bone density, the risk of osteoporosis or osteopenia and even the risk of sarcopenia and sarcopenic obesity have been increasing as well as gaining in importance. There is still, however, a lack of studies which examine the mutual link and interaction between the individual parameters of frailty amongst elderly. The aim of the current study was to assess the relationship between selected parameters of frailty amongst elderly women in the Olomouc region.

\section{Methods}

\section{Participants}

Two hundred and twenty five women aged 60-81 years participated in the measurements. They were tested in the anthropometric laboratory at the Faculty of Physical Culture, Palacký University Olomouc. The sample consisted of students of the University of the Third Age (U3A) of Palacký University Olomouc and women attending clubs for seniors in Olomouc. Differences in rates of individual measurements are given by the fact that in some women it was not possible to measure all the parameters (disease, injury). All of the women (225) participated in the measurements of body composition, 219 women participated in the measurements of muscle strength and 194 women participated in the measurements of bone density. The project was carried out in compliance with the agreement of the Ethics Committee of the Faculty of Physical Culture, Palacký University Olomouc, with reference number 56/2012.

\section{Measurements}

The data collection took place from 2013 to 2015. Height was measured using the A-226 anthropometer (Trystom, Olomouc, Czech Republic) with an accuracy of $0.5 \mathrm{~cm}$, weight (with an accuracy of $0.5 \mathrm{~kg}$ ) and body composition using the InBody 720 machine (Biospace, Seoul, South Korea), which uses the method of multi-frequency bioelectrical impedance (DSM-BIA). InBody 720 uses alternating electric current with different frequencies $(1-1000 \mathrm{kHz})$. Contact with the body is by means of 8 touch sensing electrodes and allows for an analysis of 5 body segments (left and right arm, left and right leg and trunk). Using the InBody 720, the weight is differentiated into total body water (intracellular and extracellular), proteins, minerals and body fat. The method is unified and the measurements took place under standard conditions. In order to assess the risk of obesity, health indicators of body composition were applied - body fat mass (BFM, kg, \%), body fat mass index (BFMI, $\mathrm{kg} / \mathrm{m}^{2}$ ), fat-free mass (FFM, $\mathrm{kg}$ ), fat-free mass index (FFMI, $\left.\mathrm{kg} / \mathrm{m}^{2}\right)$, skeletal muscle mass (SMM, $\mathrm{kg}$ ), body cell mass (BCM, kg), body cell mass index (BCMI, $\mathrm{kg} / \mathrm{m}^{2}$ ), the amount of visceral fat $\left(\mathrm{VFA}, \mathrm{cm}^{2}\right)$ and body mass index $\left(\mathrm{BMI}, \mathrm{kg} / \mathrm{m}^{2}\right)$. For a clearer description, the size of the basal metabolic rate (BMR, kcal) is also presented. The criteria of ranking into categories, based on the above listed indexes, are presented in Table 1. 
Information on bone density was obtained using an EXA 3000 local densitometer (Osteosys, Seoul, South Korea) which evaluates bone density in the areas of the heel and forearm. The indication of the decrease in bone density (risks of osteoporosis and osteopenia) was carried out on the basis of the value of bone mineral density (BMD, $\mathrm{g} / \mathrm{cm}^{2}$ ). In order to compare these to the reference values of healthy individuals of the same gender and ethnicity, we made use of information on the T-score (Osteosys, 2005).

Muscle strength in the areas of flexors of the hand was also evaluated using the digital pinch grip (MIE Medical Research Company, Leeds, United Kingdom). The participants took the pinch grip into hand and tried to develop maximum grip strength in 5 seconds. MIE's patented design measures a force irrespective of hand position. According to the Camry Electronic Hand Dynamometer Instruction Manual for women is the norm in the range from 168.7 to $304.1 \mathrm{~N}$ in the age category $60-64$, from 151.1 to $266.8 \mathrm{~N}$ in the age category 65-69 and from 144.2 to $240.3 \mathrm{~N}$ for women above 70 years of age. Women with a lower value than the norm were called as weak, women with a higher value than the norm were called as strong.

The participants were informed about the rules, which were essential to respect so as to acquire valid data relating to body composition, bone density and muscle strength. The measurements were performed in the morning in compliance with standard conditions.

\section{Statistical analysis}

Data obtained from the InBody 720 Body Composition Analyser (Biospace, Seoul, South Korea) were processed using the Lookin Body 3.0 software package (Biospace, Seoul, South Korea), data from the EXA

Table 1

Classification of BMI, FMI and FFMI in women - modified according to Kyle, Morabia, Schutz, and Pichard (2004); World Health Organization (2004)

\begin{tabular}{lccc}
\hline Classification & $\begin{array}{c}\text { BMI } \\
\left(\mathrm{kg} / \mathrm{m}^{2}\right)\end{array}$ & $\begin{array}{c}\text { BFMI } \\
\left(\mathrm{kg} / \mathrm{m}^{2}\right)\end{array}$ & $\begin{array}{c}\text { FFMI } \\
\left(\mathrm{kg} / \mathrm{m}^{2}\right)\end{array}$ \\
\hline Underweight & $\leq 18.4$ & $\leq 3.8$ & $\leq 14.5$ \\
Normal range & $18.5-24.9$ & $3.9-8.1$ & $14.6-16.7$ \\
Overweight & $25-29.9$ & $8.2-11.7$ & $16.8-18.1$ \\
Obese & $\geq 30$ & $\geq 11.8$ & $\geq 18.2$ \\
\hline
\end{tabular}

Note. $\quad \mathrm{BMI}=$ body mass index; $\mathrm{BFMI}=$ body fat mass index; FFMI $=$ fat-free mass index.
3000 device using EXA 3000 diagnostics software (Version 3.02.07b; Osteosys, Seoul, South Korea), and data from the hand dynamometer were transferred to MS Excel (Version 2010; Microsoft, Redmond, WA, USA) sheets. The descriptive characteristics and the data analysis were carried out using the statistical program Statistica (Version 12.0; StatSoft, Tulsa, OK, USA). Statistical significance was set at levels $\alpha=.05, \alpha=.01, \alpha=.001$. Normal distribution was tested by Kolmogorov-Smirnov test and data showed normal data distribution. In order to verify the size of the associations, correlation coefficients according to Pearson ( $r p$ ) were calculated. In order to interpret the values of the correlation coefficient, the division was adopted of Chráska (1998), with $r=1$ meaning perfect dependency, $1.00>r \geq .90$ is extremely high dependency, $.90>r \geq .70$ is high dependency, .70>r $r .40$ is medium dependency, .40>r $\geq .20$ low dependency and $.20>r \geq .00$ is weak dependency and $r=0$ is independency.

\section{Results}

225 women were included in the measurement of body composition with the average age of $67.7 \pm 6.4$ years old, height $161.0 \pm 6.0 \mathrm{~cm}$ and weight $72.6 \pm 13.5 \mathrm{~kg}$. When assessing their health risks on the basis of selected somatic indexes and indicators of body composition, the elderly women were assessed as being at risk. When considering BMI $\left(28.0 \pm 5.1 \mathrm{~kg} / \mathrm{m}^{2}\right)$ they were found in the overweight category. The amount of BFM was also high. The average value of BFM $(37.4 \pm 7.1 \%)$ placed the women in the obese category

Table 2

The selected parameters of body composition

\begin{tabular}{lrr}
\hline Variable & Mean & \multicolumn{1}{c}{$S D$} \\
\hline BMI $\left(\mathrm{kg} / \mathrm{m}^{2}\right)$ & 28.0 & 5.1 \\
BMR $(\mathrm{kcal})$ & $1,336.1$ & 110.7 \\
BFM $(\mathrm{kg})$ & 27.85 & 10.12 \\
BFM (\%) & 37.39 & 7.09 \\
VFA (cm $\left.{ }^{2}\right)$ & 130.24 & 38.69 \\
FFM $(\mathrm{kg})$ & 44.73 & 5.13 \\
SMM $(\mathrm{kg})$ & 24.21 & 3.03 \\
BCM $(\mathrm{kg})$ & 28.79 & 3.33 \\
BMC $(\mathrm{kg})$ & 2.63 & 0.30 \\
\hline
\end{tabular}

Note. $\quad \mathrm{BMI}=$ body mass index; $\mathrm{BMR}=$ basal metabolic rate; $\mathrm{BFM}=$ body fat mass; $\mathrm{VFA}=$ visceral fat area; FFM = fat-free mass; $\mathrm{SMM}=$ skeletal muscle mass; $\mathrm{BCM}=$ body cell mass; $\mathrm{BMC}=$ bone mineral content. 
and the average value of VFA $\left(130.2 \pm 38.7 \mathrm{~cm}^{2}\right)$ was above the limit determining abdominal obesity. The value of the BFMI of $10.8 \pm 4.0 \mathrm{~kg} / \mathrm{m}^{2}$ and the values of the FFMI of $17.2 \pm 1.5 \mathrm{~kg} / \mathrm{m}^{2}$ are above the values recommended for this age category and gender (Table 1). A review of selected parameters of body composition is presented in Table 2 .

Handgrip strength was varied. It ranged from $84.8 \mathrm{~N}$ to $341.3 \mathrm{~N}$ in the right hand and from $74.2 \mathrm{~N}$ to $344.5 \mathrm{~N}$ in the left hand. The decrease in muscle strength in relation to age is presented in Table 3.

Table 3

The muscle strength (mean $\pm S D$ ) in age categories

\begin{tabular}{|c|c|c|c|}
\hline \multirow{2}{*}{$\begin{array}{l}\text { Age category } \\
\text { (years) }\end{array}$} & \multirow[b]{2}{*}{$n$} & \multicolumn{2}{|c|}{ Grip strength $(\mathrm{N})$} \\
\hline & & Right hand & Left hand \\
\hline $60-64.9$ & 90 & $252.5 \pm 46.8$ & $241.8 \pm 47.9$ \\
\hline $65-69.9$ & 55 & $229.0 \pm 47.1$ & $217.3 \pm 40.4$ \\
\hline $70-74.9$ & 38 & $202.9 \pm 43.6$ & $193.5 \pm 40.9$ \\
\hline $75-79.9$ & 22 & $191.7 \pm 31.3$ & $183.5 \pm 44.1$ \\
\hline $80-84.9$ & 14 & $180.5 \pm 48.4$ & $163.1 \pm 33.4$ \\
\hline
\end{tabular}

The average value of BMD in the area of the right forearm was $0.36 \pm 0.08 \mathrm{~g} / \mathrm{cm}^{2}(\mathrm{~T}$-score $=-2.12)$ and $0.33 \pm 0.07 \mathrm{~g} / \mathrm{cm}^{2}$ (T-score $\left.=-2.59\right)$ for the left arm.
The values for the heel bone were higher. The value was $0.47 \pm 0.11 \mathrm{~g} / \mathrm{cm}^{2}$ (T-score $=-0.57$ ) for the right calcaneus and $0.46 \pm 0.11 \mathrm{~g} / \mathrm{cm}^{2}$ (T-score $=-0.64$ ) for the left calcaneus. The average values for the right and left heel bone were assessed to be without risk of reduced bone density, while the value of the right forearm was at risk for osteopenia occurrence and the left forearm was even at the risk of osteoporosis occurrence.

The links between body composition, muscle strength and bone density appeared as statistically significant (Table 4 and 5). The size of associations based on the Pearson correlation was primarily low or weak. The associations between body composition and muscle strength were of a low or medium dependency. Positive medium dependency was found in both hands in connection with the amount of FFM, SMM, BCM and BMR. Negative medium dependency was found between the age and the strength of the left and right hands.

Positive medium dependency was found in the link between bone density and body composition, particularly in the link between BMD of the left and right heel bones and the amount of FFM, SMM, BCM and BMR. Medium dependency was also found between BMD of the right calcaneus and height. The link between muscle strength and bone density can be described as weak, although it was statistically significant.

Table 4

The relationship between selected parameters of body composition, muscular strength in the hand flexors and bone density using Pearson correlation coefficient

\begin{tabular}{|c|c|c|c|c|c|c|}
\hline \multirow[b]{2}{*}{ Variable } & \multicolumn{2}{|c|}{ Grip strength $(\mathrm{N}), n=219$} & \multicolumn{4}{|c|}{ Bone mineral density $\left(\mathrm{g} / \mathrm{cm}^{2}\right), n=194$} \\
\hline & Right hand & Left hand & Right forearm & Left forearm & Right calcaneus & Left calcaneus \\
\hline Age (years) & $-.52 * * *$ & $-.53 * * *$ & $-.27 * * *$ & $-.30 * * *$ & $-.17 *$ & $-.21 * *$ \\
\hline Height $(\mathrm{cm})$ & $.36^{* * *}$ & $.35 * * *$ & $.33 * * *$ & $.32 * * *$ & $.40 * * *$ & $.37 * * *$ \\
\hline Weight (kg) & $.20 * *$ & .10 & $.19 * *$ & $.26 * * *$ & $.39 * * *$ & $.33 * * *$ \\
\hline BFM (kg) & .04 & -.08 & .08 & $.15^{*}$ & $.26 * * *$ & $.22 * *$ \\
\hline BFM (\%) & -.13 & $-.25 * * *$ & -.02 & .04 & .13 & .11 \\
\hline VFA $\left(\mathrm{cm}^{2}\right)$ & -.08 & $-.20 * *$ & .01 & .08 & $.18^{*}$ & $.15^{*}$ \\
\hline FFM (kg) & $.44 * * *$ & $.42 * * *$ & $.32 * * *$ & $.37 * * *$ & $.48 * * *$ & $.41 * * *$ \\
\hline SMM (kg) & $.48 * * *$ & $.46 * * *$ & $.33 * * *$ & $.38 * * *$ & $.49 * * *$ & $.42 * * *$ \\
\hline BCM (kg) & $.48 * * *$ & $.46^{* * *}$ & $.35 * * *$ & $.39 * * *$ & $.49 * * *$ & $.42 * * *$ \\
\hline BMC (kg) & $.35 * * *$ & $.34 * * *$ & $.30 * * *$ & $.35 * * *$ & $.47 * * *$ & $.42 * * *$ \\
\hline BMR (kcal) & $.44 * * *$ & $.42 * * *$ & $.32 * * *$ & $.37 * * *$ & $.48 * * *$ & $.41 * * *$ \\
\hline BMI $\left(\mathrm{kg} / \mathrm{m}^{2}\right)$ & .06 & -.04 & .05 & .13 & $.22 * *$ & $.17 *$ \\
\hline BCMI $\left(\mathrm{kg} / \mathrm{m}^{2}\right)$ & $.31^{* * *}$ & $.30 * * *$ & $.15^{*}$ & $.22 * *$ & $.28 * * *$ & $.21 * *$ \\
\hline BFMI $\left(\mathrm{kg} / \mathrm{m}^{2}\right)$ & -.03 & $-.14^{*}$ & .02 & .09 & $.17^{*}$ & .14 \\
\hline FFMI $\left(\mathrm{kg} / \mathrm{m}^{2}\right)$ & $.27 * * *$ & $.25 * * *$ & .13 & $.20 * *$ & $.27 * * *$ & $.20 * *$ \\
\hline
\end{tabular}

Note. $\mathrm{BFM}=$ body fat mass; $\mathrm{VFA}=$ visceral fat area; $\mathrm{FFM}=$ fat-free mass; $\mathrm{SMM}=$ skeletal muscle mass; $\mathrm{BCM}=$ body cell mass; $\mathrm{BMC}=$ bone mineral content; $\mathrm{BMR}=$ basal metabolic rate; $\mathrm{BMI}=$ body mass index; $\mathrm{BCMI}=$ body cell mass index; $\mathrm{BFMI}=$ body fat mass index; FFMI $=$ fat-free mass index. $\quad * p<.05, * * p<.01, * * * p<.001$. 
Table 5

The relationship between muscle strength in the hand flexors and bone mineral density using Pearson correlation coefficient

\begin{tabular}{lcc}
\hline & \multicolumn{2}{c}{ Grip strength $(\mathrm{N})$} \\
\cline { 2 - 3 } & Right hand & Left hand \\
\hline Right forearm BMD $\left(\mathrm{g} / \mathrm{cm}^{2}\right)$ & $.28^{* * *}$ & $.25^{* * *}$ \\
Left forearm BMD $\left(\mathrm{g} / \mathrm{cm}^{2}\right)$ & $.26^{* * *}$ & $.24^{* *}$ \\
Right calcaneus BMD $\left(\mathrm{g} / \mathrm{cm}^{2}\right)$ & $.28^{* * *}$ & $.22^{* *}$ \\
Left calcaneus BMD $\left(\mathrm{g} / \mathrm{cm}^{2}\right)$ & $.29^{* * *}$ & $.18^{*}$ \\
\hline
\end{tabular}

Note. $\mathrm{BMD}=$ bone mineral density.

$* p<.05, * * p<.01, * * p<.001$.

\section{Discussion}

Evaluation of obesity by BMI, BFM and VFA showed a high health risk. The amount of BFM $37.4 \%(27.9 \mathrm{~kg})$ serves to confirm the higher share of the fat component. This finding is in compliance with the results of studies which examined the proportion of fat component and FFM amongst elderly women. The average value of the amounts of fat mass were above the $34 \%$ threshold also in other studies of the elderly population (Gába et al., 2009; Kyle et al., 2004).

Although according to BMI, the sample is ranged in the category of overweight, an assessment based on the percentage of fat, ranges this sample into the category of obesity, which means the percentage of body fat surpasses the level of $35 \%$ according to Heyward and Wagner (2004).

A redistribution of fat tissue occurs at an elderly age, primarily in the abdominal area (Toth et al., 2000). Elderly women manifested a high amount of VFA $\left(130.2 \mathrm{~cm}^{2}\right)$ indicating health risks related to abdominal obesity. The values are very similar to those in a study by Gába and Přidalová (2014), which confirmed the increase in VFA after menopause. The average value of VFA was $122.5 \mathrm{~cm}^{2}$ amongst 50 year old women, $135.8 \mathrm{~cm}^{2}$ amongst 60 year old women, $155.3 \mathrm{~cm}^{2}$ for women above 70 years of age. A study by Kim, Choi, and Yum (2006) has a preference for VFA as an indicator of increasing risk of obesity and related illnesses, value of VFA $103.8 \mathrm{~cm}^{2}$ (74.5\% sensitivity and $64.8 \%$ specificity, $p<.001)$ is stated as a cut-off value. The higher amount of VFA is also linked according to studies with a lower amount of muscle mass (Song et al., 2004; Yamada, Moriguch, Mitani, Aoyoma, \& Arai, 2014).

The amount of FFM was $44.7 \mathrm{~kg}$ on average. A study by Schutz, Kyle, and Pichard (2002) points at a decrease in FFM over the course of aging. Women aged from 25 to 54 years demonstrated FFM $43 \mathrm{~kg}$, in the age category 55-74, while the amount of FFM decreased to $42.1 \mathrm{~kg}$. A decline of FFM is apparent in the decades after menopause in a study by Gába and Přidalová (2014). The average value FFM was $45.4 \mathrm{~kg}$ for 50 years old, a decrease of $44.6 \mathrm{~kg}$ for 60 years old women. The greatest decrease is apparent in women over the age of 70 , with a FFM of $42.0 \mathrm{~kg}$. A lower amount of FFM can be observed in the sample which confirms the decrease in FFM along with age.

The amount of SMM is also a component of the FFM. Its average value in women was $24.2 \mathrm{~kg}(29.5 \%$ of the total weight). In a study by Gába et al. (2009) the average value of SMM was $24.8 \mathrm{~kg}$ (35.3\% of the total weight). Research by Yamada et al. (2014) in Japanese women and men aged from 40 to 88 years confirmed a gradual decrease in muscle mass in both genders. The decrease in muscle mass amongst men was higher $(10.8 \%)$ than in women $(6.4 \%)$. Thomas (2007) and Hughes et al. (2002) argue for a decrease in muscle mass after the age of 50 by $1-2 \%$ annually. This decrease is observable in the active and sedentary population. Muscle strength also decreases with a lowering in muscle mass. Fried et al. (2001) uses the term muscle weakness for the decrease in muscle strength and states the risk values of grip strength of the dominant hand for the Jamar hand dynamometer based on BMI size. The risk level is $17 \mathrm{~kg}$ for women with $\mathrm{BMI} \leq 23.0 \mathrm{~kg} / \mathrm{m}^{2}, 17.3 \mathrm{~kg}$ for BMI $23.1-26.0 \mathrm{~kg} / \mathrm{m}^{2}$, $18.0 \mathrm{~kg}$ for BMI $26.1-29.0 \mathrm{~kg} / \mathrm{m}^{2}$ and $21.0 \mathrm{~kg}$ for BMI over $29.0 \mathrm{~kg} / \mathrm{m}^{2}$. Based on this evaluation and according to the Camry Electronic Hand Dynamometer Instruction Manual, none of the age categories demonstrated the risk of muscle weakness in their average value. Only $4.6 \%$ of the elderly women can be assessed as weak, $79 \%$ of women were in the norm, and $16.4 \%$ of women were assessed as strong. Daly et al. (2013) examined the decrease in muscle strength using the strength of grip of the dominant hand and confirmed a consistent loss of muscle strength after the age of 50 by $2.2-3.1 \%$ per year regardless the gender and age category. Similar results were also found concerning a loss of muscle strength by $2.4-2.8 \%$ per year in a study by Forrest, Zmuda, and Cauley (2007). The current study also indicated differences which ranged from $2.8 \%$ to $6.0 \%$ between age categories. The greatest difference was found in the transition into the category above 70 years of age.

Menopause is a significant factor for changes in bone tissue. Ho et al. (2008) have found that there is a decrease in bone tissue by $0.5 \%$ per year in premenopause women. There is a transitional increase in the period of menopause to $2-2.5 \%$ and a decrease in the post-menopause period to $1.5 \%$ per year. In our study $35.5 \%$ of women were assessed as non-risk, $36.9 \%$ 
of women indicated a risk of osteopenia and $27.6 \%$ of women indicated a risk of osteoporosis. Worse results were found in the left forearm, while in 53\% of women the T-score indicated a risk of osteoporosis. Only 7\% of women were evaluated as non-risk. Research by Warming et al. (2002) also confirmed risk values in the area of the forearm and observed changes in bone density after menopause and identified the highest pace of loss of bone density in the area of the forearm $(-0.47$ to $1.07 \%$ per year). An increased pace in the loss of bone tissue in women above the age of 60 in the area of the forearm has also been confirmed by research by Daly et al. (2013). Research carried out in Wroclaw (Ignasiak et al., 2011) with the use of an EXA 3000 densitometer revealed more women with risk of osteoporosis $(55 \%)$, with a normal value of BMD only being found in $17 \%$ of women. An average value of BMD $0.34 \mathrm{~g} / \mathrm{cm}^{2}$ (T-score -2.18) in the area of the forearm corresponds to the measured values and confirms increased risk of fractures in this area.

Skrzek et al. (2011) observed changes in bone density in the area of the femoral neck on the basis of the DEXA method in the age group of 40-88. In women over 65 years of age the percentage of women with the risk of osteopenia and osteoporosis occurrence increases. The group of women with osteopenia is the most common at the age of 65 . Research by Khosla and Melton (2007) also points to a higher risk of osteopenia.

The mutual interrelations of factors such as changes in body composition, decreased bone density and decreased muscle strength over the course of aging all point to risks of frail elderly, risk of falls and a decrease of self-sufficiency (Kalvach et al., 2008; Topinková, 2002).

Several statistically significant correlations have been found between the examined individual aspects of frailty in elderly women in the current sample. A positive medium correlation was found between FFM, SMM and the size of muscle strength. A study by Pasco, Holloway, Brennan-Olsen, Moloney, and Kotowicz (2015) has also proposed a positive correlation between muscle strength and FFM. A negative association was demonstrated between age and muscle strength. A number of authors have discussed the decrease in muscle strength after the age of 50. Berková et al. (2013) has stated a decrease in muscle mass by $1.2 \%$, a decrease in muscle strength by $1.5 \%$ in women after the age of 50 and by $3 \%$ after the age of 60 .

A medium association was found in certain parameters of body composition (SMM, FFM, BCM, BMR) and bone density. An association between bone density and the amount of fat mass and total body water was found in research by Ignasiak, Skrzek, and
Dąbrowska (2009). In the current sample the interrelations between the parameters were low. A medium association between BFM, FFM and BMD in women after menopause was determined in a study by Lim et al. (2004). A positive correlation was found between SMM and BMD in a study by Kritz-Silverstein and Barrett-Connor (1994). Research by Dytfeld, IgnaszakSzszepaniak, Gowin, Michalak, and Horst-Sikorska (2011) focused on women with the diagnosis of postmenopausal osteoporosis has confirmed the relationship between BMD and FFM. Research by Greco et al. (2010) and Gába and Kapuš (2012) have also pointed out the relationship between the fat component and its positive effect on BMD.

Although the correlation between muscle strength and bone density found in the current research is low or weak, this association is still statistically significant $(p<.001)$. A positive association between muscle strength and BMD has also been confirmed in research by Pasco et al. (2015), who focused on the area of the waist and hip bone when they assessed muscle strength and bone density. Research by Daly et al. (2013) indicates more apparent loss of BMD in the age categories of 50-60 and 60-70 in women. Similarly, muscle strength also decreased with age. When comparing BMD and the decrease in muscle strength in annual percentage changes in age categories, an increased loss of muscle strength can be observed (on average by $1-3 \%$ ) in relation to the loss of BMD.

\section{Conclusion}

When considering BMI, elderly women can be ranged into the category of overweight, and in terms of the fat component, they are on average obese individuals with abdominal obesity. Muscle strength was in the norm amongst nearly $80 \%$ of women. Bone density was reduced in the area of the forearm. The current findings indicated a moderate correlation for the most of observed somatic parameters that are related to elderly frailty.

\section{Acknowledgments}

This work was supported by research grants from the Czech Science Foundation (no. 15-13980S) and Palacký University Olomouc (no. IGA_FTK_2015_006).

\section{Conflict of interest}

There were no conflicts of interest. 


\section{References}

Abellan van Kan, G., Rolland, Y., Andrieu, S., Bauer, J., Beauchet, O., Bonnefoy, M., ... Vellas, B. (2009). Gait speed at usual pace as a predictor of adverse outcomes in community-dwelling older people an International Academy on Nutrition and Aging (IANA) task force. Journal of Nutrition. Health and Aging, 13, 881-889.

Berková, M., Berka, Z., \& Topinková, E. (2013). Problematika seniorského věku: Stařecká křehkost, sarkopenie a disabilita [The older age issues: The frailty, sarcopenia and disability]. Practicus, 2, 13-17.

Cesari, M., Landi, F., Vellas, B., Bernabei, R., \& Marzetti, E. (2014). Sarcopenia and physical frailty: Two sides of the same coin. Frontiers in Aging Neuroscience, 6, 192.

Chráska, M. (1998). Základy výzkumu v pedagogice [Basics of education research]. Olomouc, Czech Republic: Palacký University Olomouc.

Clegg, A., Young, J., Iliffe, S., Rikkert, M. O., \& Rockwood, K. (2013). Frailty in elderly people. Lancet, 381, 752-762.

Cruz-Jentoft, A. J., Baeyens, J. P., Bauer, J. M., Boirie, Y., Cederholm, T., Landi, F., ... Zamboni, M. (2010). Sarcopenia: European consensus on definition and diagnosis. Report of the European Working Group on Sarcopenia in Older People. Age and Ageing, 39, 412-423.

Daly, R. M., Rosengren, B. E., Alwis, G., Ahlborg, H. G., Sernbo, I., \& Karlsson, M. K. (2013). Gender specific age-related changes in bone density, muscle strength and functional performance in the elderly: A 10 year prospective population-based study. BMC Geriatrics, 13, 71.

Dytfeld, J., Ignaszak-Szczepaniak, M., Gowin, E., Michalak, M., \& Horst-Sikorska, W. (2011). Influence of lean and fat mass on bone mineral density (BMD) in postmenopausal women with osteoporosis. Archives of Gerontology and Geriatrics, 53, 237-242.

Evans, W. J., \& Campbell, W. W. (1993). Sarcopenia and age-related changes in body composition and functional capacity. Journal of Nutrition, 123, 465-468.

Forbes, G. B. (1999). Longitudinal changes in adult fat-free mass: Influence of body weight. American Journal of Clinical Nutrition, 70, 1025-1031.

Forrest, K. Z., Zmuda, J. M., \& Cauley, J. A. (2007). Patterns and correlates of muscle strength loss in older women. Gerontology, 53, 140-147.

Fried, L. P., Tangen, C. M., Walston, J., Newman, A. B., Hirsch, C., Gottdiener, J., ... McBurnie, M. A. (2001). Frailty in older adults: Evidence for a phenotype. Journals of Gerontology. Series A, Biological Sciences and Medical Sciences, 56, 146-156.

Gába, A., \& Kapuš, O. (2012). Tělesné složení jako faktor ovlivňující kostní denzitu u postmenopauzálních žen [Body composition as a factor influencing bone density in postmenopausal women]. Osteologický bulletin, 17, 59-64.

Gába, A., \& Přidalová, M. (2014). Age-related changes in body composition in a sample of Czech women aged 18-89 years: A cross-sectional study. European Journal of Nutrition, 53, 167-176.

Gába, A., Přidalová, M., \& Zajac-Gawlak, I. (2014). Posouzení objektivity hodnocení výskytu obezity na základě body mass indexu vzhledem k procentuálnímu zastoupení tělesného tuku u žen ve věku 55-84 let [Evaluation of accuracy of body mass index in diagnosing of obesity in relation to body fat percentage in female aged 55-84 years]. Časopis lékařnu českých, 153, 22-27.

Gába, A., Riegerová, J., \& Přidalová, M. (2009). Hodnocení tělesného složení u seniorek - studentek U3V pomocí InBody 720 [Evaluation of body composition in senior women - students of U3A using device InBody 720]. Česká antropologie, 59(1-2), 25-28.

Greco, E., Fornari, R., Rossi, F., Santiemma, V., Prossomariti, G., Annoscia, C., ... Migliaccio, S. (2010). Is obesity protective for osteoporosis? Evaluation of bone mineral density in individuals with high body mass index. International Journal of Clinical Practice, 64, 817-820.

Heyward, V., \& Wagner, D. (2004). Applied body composition assessment. Champaign, IL: Human Kinetics.

Ho, S. C., Chan, S. G., Yip, Y. B., Chan, C. Y., Woo, J. F., \& Sham, A. (2008). Change in bone mineral density and its determinants in pre- and perimenopausal Chinese women: The Hong Kong perimenopausal women osteoporosis study. Osteoporosis International, 19, 1785-1796.

Hughes, V. A., Frontera, W. R., Roubenoff, R., Evans, W. J., \& Fiatarone Singh, M. A. (2002). Longitudinal changes in body composition in older men and women: Role of body weight change and physical activity. American Journal of Clinical Nutrition, 76, 473-481.

Ignasiak, Z., Skrzek, A., \& Dąbrowska, G. (2009). Bone mineral density and body composition of senior female students of the university of the third age in view of their diverse physical activity. Human Movement, 10, 109-115.

Ignasiak, Z., Skrzek, A., Sławińska, T., Rożek-Piechura, K., Steciwko, A., Domaradzki, J., ... Posłuszny, P. (2011). The initial assessment of the biological condition of elderly women from Wroclaw. Gerontologia Polska, 19, 66-70.

Kalvach, Z., Zadák, Z., Jirák, R., Zavázalová, H., Holmerová, I., \& Weber, P. (2008). Geriatrické syndromy a geriatrický pacient [Geriatric syndromes and geriatric patient]. Prague, Czech Republic: Grada Publishing.

Kalvach, Z., Zadák, Z., Jirák, R., Zavázalová, H., \& Sucharda, P. (2004). Geriatrie a gerontologie [Geriatrics and gerontology]. Prague, Czech Republic: Grada Publishing.

Khosla, S., \& Melton, L. J. (2007). Osteopenia. New England Journal of Medicine, 356, 2293-2300.

Kim, J. A., Choi, Ch. J., \& Yum, K. S. (2006). Cut-off values of visceral fat area and waist circumference: Diagnostic criteria for abdominal obesity in a Korean population. Journal of Korean Medical Science, 21, 1048-1053.

Kritz-Silverstein, D., \& Barrett-Connor, E. (1994). Grip strength and bone mineral density in older women. Journal of Bone and Mineral Research, 9, 45-51.

Kyle, U. G., Morabia, A., Schutz, Y., \& Pichard, C. (2004). Sedentarism affects body fat mass index and fat-free mass index in adults aged 18 to 98 years. Nutrition, 20, 255-260.

Lim, S., Joung, H., Shin, Ch. S., Lee, H. K., Kim, K. S., Shin, E. K., ... Cho, S. (2004). Body composition changes with age have gender-specific impacts on bone mineral density. Bone, 35, 792-798.

NIH Consensus Development Panel on Osteoporosis Prevention, Diagnosis, and Therapy. (2001). Osteoporosis prevention, diagnosis, and therapy. JAMA, 285, 785-795. 
Osteosys. (2005). Osteosys EXA-3000. Retrieved from http:// www.osteosys.com/osteosys/inc.php?inc=e_sub2/sub3\&s kin[head] $=$ esub2\&skin[foot] $=$ edefault

Pasco, J. A., Holloway, K. L., Brennan-Olsen, S. L., Moloney, D. J., \& Kotowicz, M. A. (2015). Muscle strength and areal bone mineral density at the hip in women: A crosssectional study. BMC Musculoskeletal Disorders, 16, 1-6.

Pavelka, K., \& Rovenský, J. (2003). Klinická revmatologie [Clinical rheumatology]. Prague, Czech Republic: Galén.

Prokešová, E., Šteffl, M., Petr, M., \& Kohlíková, E. (2012). Možnosti diagnostiky a prevence sarkopenie [Diagnostics and prevention of sarcopenia]. Česká kinantropologie, 16(3), 26-31.

Rockwood, K., Hogan, D. B., \& MacKnight, C. (2000). Conceptualisation and measurement of frailty in elderly people. Drugs \& Aging, 17, 295-302.

Rodríguez-Mañas, L., Féart, C., Mann, G., Viña, J., Chatterji, S., Chodzko-Zajko, W., ... Vega, E. (2013). Searching for an operational definition of frailty: A Delphi method based consensus statement: The frailty operative definition-consensus conference project. Journals of Gerontology. Series A, Biological Sciences and Medical Sciences, 68, 62-67.

Schutz, Y., Kyle, U. G., \& Pichard, C. (2002). Fat-free mass index and fat mass index percentiles in Caucasians aged 18-98 year. International Journal of Obesity and Related Metabolic Disorders, 26, 953-960.

Shephard, R. J. (1997). Aging, physical activity, and health. Champaign, IL: Human Kinetics.

Skrzek, A., Ignasiak, Z., \& Koziel, S. (2011). Different involutionary changes in bone mineral density with age in free skeletal sites in healthy Polish women. Journal of Comparative Human Biology, 62, 359-367.

Skrzek, A., Ignasiak, Z., Sławińska, T., Domaradzki, J., Fugiel, J., Sebastjan, A., \& Rożek, K. (2015). Structural and functional markers of health depending on lifestyle in elderly women from Poland. Clinical Interventions in Aging, 10, 781-793
Song, M. Y., Ruts, E., Kim, J., Janumala, I., Heymsfield, S., \& Gallagher, D. (2004). Sarcopenia and increased adipose tissue infiltration of muscle in elderly AfricanAmerican women. American Journal of Clinical Nutrition, 79, 874-880.

Spirduso, W. W., Macrae, P. G., \& Francis, K. L. (2005). Physical dimensions of aging. Champaign, IL: Human Kinetics.

Suetta, C., Hvid, L. G., Justesen, L., Christensen, U., Neergaard, K., Simonsen, L., ... Aagaard, P. (2009). Effects of aging on human skeletal muscle after immobilization and retraining. Journal of Applied Physiology, 107, 1172-1180.

Teegarden, D., Proulx, W. R., Martin, B. R., Weaver, C. M., Zhao, J., McCabe, G. P., ... Johnston, C. C. (1995). Peak bone mass in young women. Journal of Bone and Mineral Research, 10, 711-715.

Thomas, D. R. (2007). Loss of skeletal muscle mass in aging: Examining the relationship of starvation, sarcopenia and cachexia. Clinical Nutrition, 26, 389-399.

Topinková, E. (2002). Muskuloskeletální a revmatická onemocnění ve stáří [Musculoskeletal and rheumatic diseases in the elderly]. Postgraduální medicína, 6, 57-65.

Toth, M. J., Tchernof, A., Sites, C. K., \& Poehlman, E. T. (2000). Effect of menopausal status on body composition and abdominal fat distribution. International Journal of Obesity and Related Metabolic Disorders, 24, 226-231.

Warming, L., Hassager, C., \& Christiansen, C. (2002). Changes in bone mineral density with age in men and women: A longitudinal study. Osteoporosis International, 13, 105-112.

World Health Organization. (2004). BMI classification. Retrieved from http://apps.who.int/bmi/index. jsp?introPage=intro_3.html

Yamada, M., Moriguch, Y., Mitani, T., Aoyama, T., \& Arai, H. (2014). Age-dependent changes in skeletal muscle mass and visceral fat area in Japanese adults from 40 to 79 years of age. Geriatrics and Gerontology International, 14, 8-14. 